\title{
CELLULAR FATTY ACID COMPOSITION IN GRAM- NEGATIVE OBLIGATELY ANAEROBIC RODS
}

\author{
EIICHI MIYAGAWA, RYOZO AZUMA,* AND TSUNEJI SUTO \\ First Research Division, National Institute of Animal Health, Tsukuba, Ibaragi 300-21, Japan \\ *Hokkaido Branch Laboratory, National Institute of Animal Health, \\ Sapporo-shi, Hokkaido 061-01, Japan
}

(Received September 1, 1978)

\begin{abstract}
The cellular fatty acid composition of 27 strains of gram-negative obligately anaerobic rods was determined by gas-liquid chromatography. Results showed that a variety of acids was detected in these organisms, and comparison of the relative amount of each of the acids was useful in distinguishing several species. A dendrogram based on their fatty acid composition was made, and this analysis appeared to be an aid in the grouping of the bacteria.
\end{abstract}

The application of gas-liquid chromatography (GLC) of fatty acids for the classification of bacteria was first attempted by Abel and Peterson (l) in 1963 and many laboratories are currently using GLC to study the cellular fatty acid composition of microorganisms because of its convenience and usefulness. These studies have rapidly expanded our knowledge of chemistry and taxonomy of closely related bacteria. Members of the genera Bacteroides and Fusobacterium in the family Bacteroidaceae that are Gram-negative, obligately anaerobic rods are commonly isolated from oral cavity, upper respiratory tract, and intestinal tracts of man and animals (2). They are also significant anaerobic pathogens in many clinical conditions (3). In recent years, they have been isolated at a high rate from the abscess of cattle and pigs. At present, 22 species are registered in the genus Bacteroides and 15 species in the genus Fusobacterium (2). The features available for the differentiation of these species are morphology, carbohydrate fermentation, final products of the metabolism, nutritional requirements, and so on. It is not easy, however, to apply all these techniques, and much time is needed to obtain final judgement according to results of these tests.

There have been some reports for arrangement of Bacteroidaceae by means of the bacterial cell compoments. HOFSTAD (4) analysed lipopolysaccharide (LPS), while FrITSCHE (5) and the authors (6) investigated lipids, in these organisms. These studies supplied an interesting information which might serve as a useful taxonomic criterion, but few reports have appeared on fatty acid composition of 
Bacteroidaceae $(5,7)$.

This paper describes the results obtained in the preliminary experiments on analysis of cellular fatty acids, centering around reference strains to clarify the taxonomical position of gram-negative, obligate anaerobes of cattle and pig origin.

\section{MATERIALS AND METHODS}

Organisms. Twenty-seven strains were used. The strains and their sources are listed in Table 1. All of them were preserved in a freeze-dried state until just before the experiment.

Table 1. Bacterial strains used.

\begin{tabular}{|c|c|}
\hline Strains & Source of strain \\
\hline Bacteroides fragilis & Dr. R. Tanaka $\leftarrow \mathrm{NCTC}^{a} 9343$ \\
\hline 2. B. fragilis var. fragilis & ATCC 23745 \\
\hline 3. B. fragilis var. vulgatus & Dr. R. Tanaka $\leftarrow \mathrm{ATCC}^{b} 8482$ \\
\hline 4. B. fragilis var. ovatus & Dr. R. Tanaka $\leftarrow$ ATCC 8483 \\
\hline 5. B. fragilis var. thetaiotaomicron & Dr. R. Tanaka $\leftarrow$ NCTC 10582 \\
\hline 6. B. fragilis var. thetaiotaomicroin & Dr. R. Tanaka $\leftarrow$ ATCC 12290 \\
\hline 7. B. ruminicola var. brevis & ATCC 19188 \\
\hline 8. B. ruminicola var. ruminicola & ATCC 19189 \\
\hline 9. B. oralis & Dr. R. Tanaka $\leftarrow$ ATCC 15930 \\
\hline 10. B. oralis $(2467$ B) & Dr. K. Ueno \\
\hline 11. B. melaninogenicus var. melaninogenicus & ATCC. 25261 \\
\hline 12. B. melaninogenicus var. melaninogenicus & ATCC 25285 \\
\hline 13. B. melaninogenicus var. melaninogenicus (Gui-1034) & Dr. K. Ueno \\
\hline 14. B. melaninogenicus var. intermedius $(\mathrm{O}-33)$ & Dr. K. Ueno \\
\hline 15. B. melaninogenicus var. asaccharolyticus (28-3) & Dr. K. Ueno \\
\hline 16. B. splachnicus & Dr. H. Werner (NCTC 10825) \\
\hline 17. B. succinogenes & ATCC 19169 \\
\hline 18. B. hypermegas & ATCC 25560 \\
\hline 19. B. furcosus & ATCC 25662 \\
\hline 20. B. multiacidus & Dr. T. Mitsuoka (ATCC 27723) \\
\hline 21. B. amylophilus & Bovine rumen \\
\hline 22. Fusobacterium varium & Dr. T. Tanaka $\leftarrow$ ATCC 8501 \\
\hline 23. F. mortiferum & Dr. T. Tanaka $\leftarrow$ ATCC 9817 \\
\hline 24. F. nucleatum & Dr. T. Tanaka $\leftarrow$ ATCC 25586 \\
\hline 25. F. nucleatum (polymorphum) & Dr. T. Tanaka $\leftarrow$ ATCC 10953 \\
\hline 26. F. fusiforme & ATCC 23726 \\
\hline 27. F. necrophorum & ATCC 25286 \\
\hline
\end{tabular}

a NCTC: National Collection of Type Culture.

$b$ ATCC: American Type Culture Collection.

Condition and harvest. These organisms, except Bacteroides amylophilus, Bacteroides ruminicola var. ruminicola, and Bacteroides succinogenes, were cultivated in meat extract-yeast extract broth (VL medium) $(8)$ containing $1 \%$ glucose in deoxygenated $\mathrm{CO}_{2}$ atmosphere for $72 \mathrm{hr}$. Of the three species mentioned above, 
B. amylophilus was cultivated in VL broth containing $1 \%$ maltose and the other two in rumen fluid broth (9) containing $0.5 \%$ glucose. The cells were harvested by centrifugation, washed three times with $0.85 \%$ saline, and freeze-dried for the following methanolysis.

Methanolysis and extraction of methyl esters. Freeze-dried cells (about $20 \mathrm{mg}$ ) were suspended in $2 \mathrm{ml}$ of methanol containing $5 \% \mathrm{HCl}$ in a screw-capped glass tube and heated at $105^{\circ}$ for $3 \mathrm{hr}$. After cooling, $1 \mathrm{ml}$ of water and $3 \mathrm{ml}$ of hexane were added, the mixture was shaken well and centrifuged at $2000 \times g$ for $5 \mathrm{~min}$. The upper phase was transferred to another tube. After this procedure was repeated three times, the hexane fraction was washed with the same volume of water, dried over anhydrous $\mathrm{Na}_{2} \mathrm{SO}_{4}$, and evaporated to dryness in vacuo. The residue which contains fatty acid methyl esters was dissolved in $60 \mu 1$ of acetonitrile and subjected to GLC. The samples obtained were preserved at $-20^{\circ}$ until analysis by GLC.

Thin-layer chromatography. In case of need to confirm hydroxy-fatty acid and dimethylacetal, part of the methyl esters was developed on a silica gel $G$ thinlayer plate with hexane: ether $(8: 2, \mathrm{v} / \mathrm{v})$, or toluene: ether $(97: 3, \mathrm{v} / \mathrm{v})$ as a solvent.

Gas-liquid chromatography. GLC of fatty acid methyl esters was carried out on a gas chromatograph (Nihon Chromato Co., Tokyo) equipped with FID. The coiled glass column used was $0.3 \times 200 \mathrm{~cm}$, packed with $10 \%$ diethylene glycol succinate polyester (DEGS) on Chromosorb W, silanized, 80-100 mesh. A nonpolar liquid-phase column $(5 \% \mathrm{SE}-30,0.3 \times 200 \mathrm{~cm})$ was also used for further characterization of fatty acids. The column temperature was $180^{\circ}$ for DEGS and $200^{\circ}$ for SE-30. Nitrogen was used as a carrier gas at a flow rate of $30 \mathrm{ml} / \mathrm{min}$.

Identification of fatty acids. Fatty acids were primarily identified by comparison of the relative retention time of their methyl esters with that of standard fatty acid methyl esters $\left(\mathrm{C}_{15: 0}, \mathrm{C}_{16: 0}, \mathrm{C}_{17: 0}, \mathrm{C}_{18: 0}, \mathrm{C}_{18: 1}, \mathrm{C}_{19: 0}, \mathrm{C}_{20: 0}\right.$, and $\mathrm{C}_{22: 0}$, Applied Science Laboratories, Inc., Chicago) using both the polar and nonpolar columns. Hydrogenation and bromination of the esters were performed by the method of BRIAN and GARDNER (10). The equivalent chain length (ECL), percentage of each acid, retention time, and the amount of each peak were calculated by the programmed computer (YHP 2108 A, Yokokawa Hewlett-Packard Co., Tokyo) and these were printed out on a teletype (YHP 2752A, Yokokawa Hewlett-Packard Co.). Details of this computation method will be reported elsewhere.

Numerical analysis. There are several ways of calculating the similarity. The following formula of BERGAN (11) was adopted:

$$
\gamma=\frac{\sum a_{i} b_{i}-n \frac{\sum a_{i}}{n} \frac{\sum b_{i}}{n}}{\sqrt{\left\{\sum a_{i}{ }^{2}-n\left(\frac{\sum a_{i}}{n}\right)^{2}\right\}\left\{\sum b_{i}{ }^{2}-n\left(\frac{\sum b_{i}{ }^{2}}{n}\right)^{2}\right\}}}
$$

where $\gamma$ is the similarity, $a_{i}$ is the peak area of a fatty acid, $b_{i}$ is the peak area of the fatty acid which corresponds to that of $a_{i}$ and $n$ is the number of peaks which 
correspond with each other. Calculation of the similarity was carried out by using the programmed computer mentioned above.

Mass spectrometry. Gas chromatographic and mass spectrometric analyses were performed on Shimadzu-LKB 9000 . The mass spectrum of fatty acid methyl esters was recorded at an electron energy of $20 \mathrm{eV}$, a trap current of $60 \mu \mathrm{A}$, an accelerating voltage of $3.5 \mathrm{kV}$, and ion source temperature of $250^{\circ}$. A coiled stainless steel column used was $0.3 \times 200 \mathrm{~cm}$, packed with $10 \%$ polyethylene glycol succinate.

\section{RESULTS}

Fatty acid composition of Gram-negative, obligately anaerobic rods

A variety of gas-liquid chromatographic profiles that depended on bacterial species used were found and 53 peaks were demonstrated in them within 60 min. The fatty acid compositions of the representative bacteria are shown in Fig. 1. Label, ECL, name, and content of these peaks are presented in Table 2. When the materials that correspond to label 19.2, 20.2, 22.0, and 22.5 were developed on the silica gel $\mathrm{G}$ thin-layer plate with hexane: ether $(8: 2, \mathrm{v} / \mathrm{v})$ as a solvent, their $R f$ value (0.13) agreed well with that of authentic 3-hydroxy-fatty acid methyl esters. The mass spectra of these peaks (Fig. 2) showed very intense peaks at $m / e 103$ and $m / e 74$ due to $\mathrm{C}_{3}-\mathrm{C}_{4}$ and $\mathrm{C}_{2}-\mathrm{C}_{3}$ cleavage, respectively. The molecular ion peak was weak, but the peaks at $m / e \mathrm{M}-18(226,240,268$, and 282 , respectively) due to loss of $\mathrm{H}_{2} \mathrm{O}$ and $\mathrm{M}-50\left(194,208,236\right.$, and 250, respectively) due to loss of $\mathrm{H}_{2} \mathrm{O}+$ $\mathrm{CH}_{3} \mathrm{OH}$ appeared, this being a typical mass spectrum for 3-hydroxy-fatty acid methyl esters (12). From these results, peaks of label 19.2, 20.2, 22.0, and 22.5
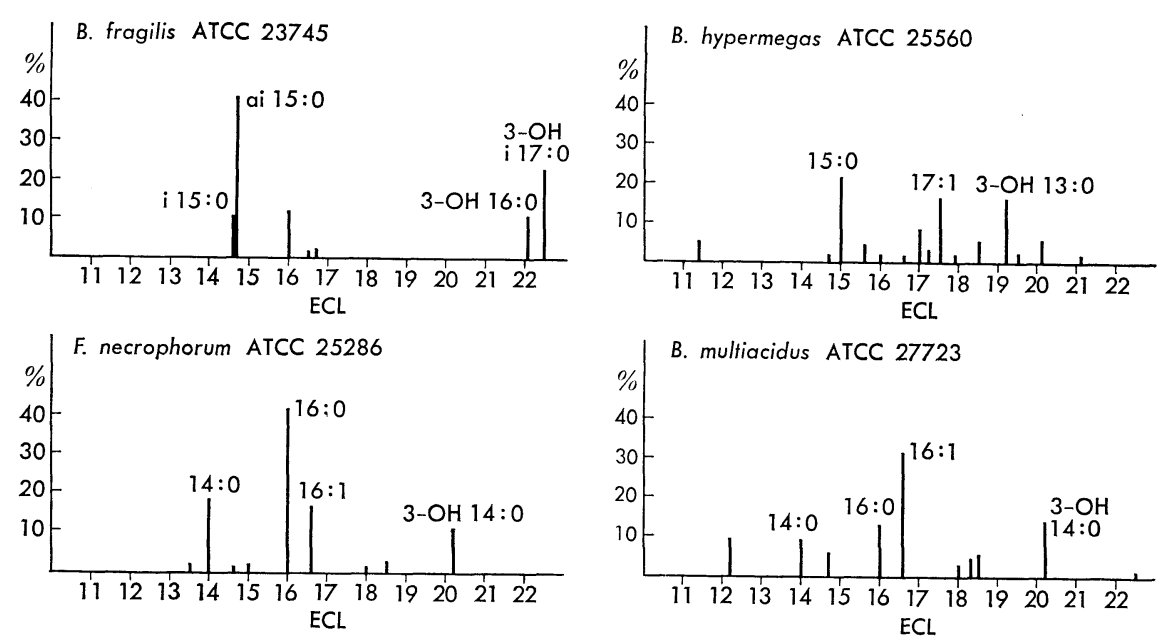

Fig. 1. Fatty acid compositions in the representative bacteria. 


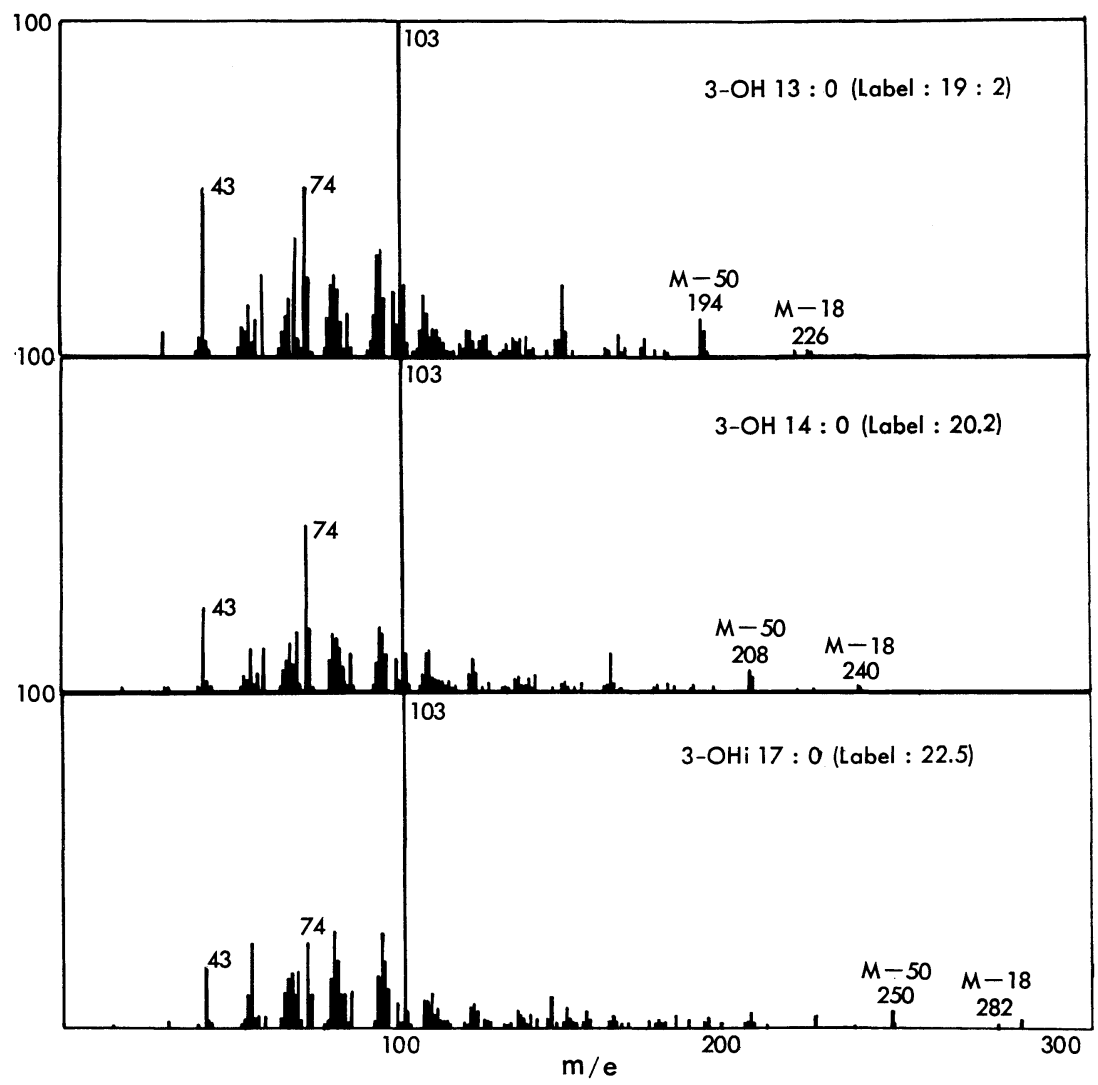

Fig. 2. Mass spectra of 3-hydroxy-fatty acid methyl esters.

were identified as 3-OH-13:0, 3-OH-14:0,3-OH-16:0, and 3-OH-iso-17: 0 , respectively. Label 18.5 or 18.6 are regarded as $\mathrm{C}_{18: 1}$ fatty acid and, by comparison with authentic standards, the former is oleic acid and the latter is cis-vaccenic acid. Both Fusobacterium species and B. amylophilus contained cis-vaccenic acid but the others contained oleic acid. The branched and odd-numbered acids were present in a large amount in all the strains belonging to Bacteroides oralis, B. ruminicola, Bacteroides fragilis, and Bacteroides melaninogenicus, but were hardly seen in all the strains belonging to Bacteroides hypermegas, Bacteroides furcosus, Bacteroides multiacidus, B. amylophilus, and Fusobacterium species. In the percentage composition of fatty acids of Bacteroides oralis (2467 B), Bacteroides splanchnicus, and B. melaninogenicus var. asaccharolyticus (28-3), a few differences were found, while they commonly contained iso-15:0 acid in a large quantity. Cellular fatty acids of all the strains belonging to B. fragilis, B. ruminicola, B. melaninogenicus, and $B$. oralis, excepting the strains, the main fatty acid of which was iso-15: 0 , mainly consisted of anteiso-15:0,3-OH-iso-17:0, 16:0, and 3-OH-16:0 acids, although a 
Table 2. Cellular fatty acid composition in

\begin{tabular}{|c|c|c|c|c|c|c|c|c|c|c|c|c|}
\hline Label & $\mathrm{ECL}^{a}$ & $\begin{array}{l}\text { Fatty } \\
\text { acids }^{b}\end{array}$ & $1^{c}$ & 2 & 3 & 4 & 5 & 6 & 7 & 8 & 9 & 10 \\
\hline 10.7 & 10.74 & $?$ & & & & & & & & & & \\
\hline 11.4 & 11.37 & $?$ & & & & & & & & & & \\
\hline $\begin{array}{l}12.2 \\
12.3 \\
12.5\end{array}$ & $\begin{array}{l}12.21 \\
12.25 \\
12.49\end{array}$ & $\begin{array}{l}? \\
? \\
?\end{array}$ & & & & & & & & $\operatorname{tr}^{d}$ & & $\operatorname{tr}$ \\
\hline 12.7 & 12.66 & $i 13: \dot{0}$ & & & & & $\operatorname{tr}$ & $\operatorname{tr}$ & 1.7 & 1.9 & $\operatorname{tr}$ & 1.2 \\
\hline 12.8 & 12.83 & ai $13: 0$ & & & 1.0 & & & $\operatorname{tr}$ & & 1.2 & & \\
\hline $\begin{array}{l}13.1 \\
13.4 \\
13.5\end{array}$ & $\begin{array}{l}13.09 \\
13.42 \\
13.53\end{array}$ & $\begin{array}{r}13: 0 \\
? \\
?\end{array}$ & & & & & & & & 0.7 & & \\
\hline 13.6 & 13.58 & $i 14: 0$ & & & 1.5 & $\operatorname{tr}$ & 2.1 & 0.6 & 0.8 & 1.9 & 2.1 & $\operatorname{tr}$ \\
\hline $\begin{array}{l}14.0 \\
14.5\end{array}$ & $\begin{array}{l}14.03 \\
14.52\end{array}$ & $\begin{array}{r}14: 0 \\
?\end{array}$ & & $\operatorname{tr}$ & 4.0 & 1.3 & 0.7 & 3.3 & 1.3 & 2.0 & 7.0 & 1.1 \\
\hline $\begin{array}{l}14.6 \\
14.7\end{array}$ & $\begin{array}{l}14.56 \\
14.73\end{array}$ & $\begin{array}{r}i 15: \dot{0} \\
\text { ai } 15: 0\end{array}$ & $\begin{array}{l}10.5 \\
41.5\end{array}$ & $\begin{array}{l}11.0 \\
41.3\end{array}$ & $\begin{array}{l}11.1 \\
42.5\end{array}$ & $\begin{array}{r}8.5 \\
40.8\end{array}$ & $\begin{array}{r}6.3 \\
48.5\end{array}$ & $\begin{array}{r}7.1 \\
45.0\end{array}$ & $\begin{array}{l}17.1 \\
22.0\end{array}$ & $\begin{array}{r}4.8 \\
28.0\end{array}$ & $\begin{array}{l}16.7 \\
20.8\end{array}$ & 56.6 \\
\hline $\begin{array}{l}15.0 \\
15.3\end{array}$ & $\begin{array}{l}14.98 \\
15.32\end{array}$ & $\begin{array}{r}15: 0 \\
?\end{array}$ & 2.0 & & 4.5 & 7.5 & & 5.6 & 22.1 & 5.6 & 6.1 & 2.3 \\
\hline $\begin{array}{l}15.5 \\
15.6\end{array}$ & $\begin{array}{l}15.52 \\
15.58\end{array}$ & $\begin{array}{r}i 16: \dot{0} \\
15: 1\end{array}$ & 0.7 & 0.7 & 1.1 & 1.7 & 3.2 & 0.8 & 2.2 & 1.1 & 0.7 & $\operatorname{tr}$ \\
\hline $\begin{array}{l}16.0 \\
16.3\end{array}$ & $\begin{array}{l}15.99 \\
16.30\end{array}$ & $\begin{array}{c}16: 0 \\
?\end{array}$ & 14.6 & 11.9 & 11.3 & 15.1 & 10.0 & 6.4 & 3.2 & 12.9 & 30.4 & 9.6 \\
\hline $\begin{array}{l}16.4 \\
16.5 \\
16.6\end{array}$ & $\begin{array}{l}16.54 \\
16.52 \\
16.59\end{array}$ & $\begin{array}{l}16: 1(\omega-9) \\
i 17: 0 \\
16: 1(\omega-7)\end{array}$ & & 1.4 & & 0.6 & 2.9 & 0.6 & 3.6 & 1.4 & 0.9 & 3.9 \\
\hline 16.7 & 16.70 & ai 17:0 & 3.5 & 2.3 & 0.7 & 3.1 & 2.8 & 1.8 & 4.8 & 2.1 & & \\
\hline $\begin{array}{l}17.0 \\
17.2\end{array}$ & $\begin{array}{l}16.97 \\
17.22\end{array}$ & $\begin{array}{r}17: 0 \\
?\end{array}$ & & & & & & & & 0.9 & & \\
\hline $\begin{array}{l}17.3 \\
17.5 \\
17.9\end{array}$ & $\begin{array}{l}17.28 \\
17.53 \\
17.86\end{array}$ & $\begin{array}{r}\dot{?} \\
17: 1 \\
?\end{array}$ & & 0.7 & & & 0.6 & & $\operatorname{tr}$ & $\operatorname{tr}$ & & $\operatorname{tr}$ \\
\hline $\begin{array}{l}18.0 \\
18.2 \\
18.3 \\
18.4\end{array}$ & $\begin{array}{l}17.97 \\
18.15 \\
18.28 \\
18.51\end{array}$ & $\begin{array}{r}18: 0 \\
? \\
? \\
i 19: 0\end{array}$ & & & & & 0.6 & & & 12.9 & & $\operatorname{tr}$ \\
\hline $\begin{array}{l}18.5 \\
18.6\end{array}$ & $\begin{array}{l}18.48 \\
18.55\end{array}$ & $\begin{array}{l}18: 1(\omega-9) \\
18: 1(\omega-7)\end{array}$ & & & & & & & & 5.8 & 0.8 & 0.6 \\
\hline $\begin{array}{l}19.1 \\
19.2\end{array}$ & $\begin{array}{l}19.07 \\
19.21\end{array}$ & 3-OH13:0 & 1.1 & 1.1 & $\operatorname{tr}$ & & 1.0 & & 1.2 & & & \\
\hline $\begin{array}{l}19.3 \\
19.5\end{array}$ & $\begin{array}{l}19.26 \\
19.48\end{array}$ & $19: \stackrel{?}{1}$ & & & & & & & & 1.3 & & $\operatorname{tr}$ \\
\hline $\begin{array}{l}20.1 \\
20.2 \\
20.4 \\
20.5 \\
20.7\end{array}$ & $\begin{array}{l}20.10 \\
20.17 \\
20.43 \\
20.49 \\
20.74\end{array}$ & $\begin{array}{c}? \\
3-\mathrm{OH} 14: 0 \\
20: 1 \\
? \\
?\end{array}$ & & & & & & & $\operatorname{tr}$ & 0.8 & & 6 \\
\hline 21.1 & 21.11 & $?$ & & & & & & 1.0 & & 2.3 & & .0 \\
\hline $\begin{array}{l}21.3 \\
21.5\end{array}$ & $\begin{array}{l}21.25 \\
21.49\end{array}$ & $?$ & & & & & 1.6 & & & 0.6 & & 0.7 \\
\hline $\begin{array}{l}22.0 \\
22.5 \\
22.7\end{array}$ & $\begin{array}{l}22.02 \\
22.49 \\
22.68\end{array}$ & $\begin{array}{l}\text { 3-OH16:0 } \\
\text { 3-OHi17:0 } \\
\text { 3-OHai 17:0 }\end{array}$ & $\begin{array}{r}8.0 \\
18.1\end{array}$ & $\begin{array}{r}6.1 \\
23.2\end{array}$ & $\begin{array}{r}9.7 \\
11.9\end{array}$ & $\begin{array}{r}7.7 \\
13.5\end{array}$ & $\begin{array}{r}2.1 \\
17.5\end{array}$ & $\begin{array}{r}10.2 \\
10.7 \\
6.7\end{array}$ & $\begin{array}{r}0.7 \\
13.6 \\
3.8\end{array}$ & $\begin{array}{l}5.2 \\
4.3\end{array}$ & $\begin{array}{r}10.1 \\
4.3\end{array}$ & $\begin{array}{r}9.2 \\
13.0\end{array}$ \\
\hline $\begin{array}{l}23.0 \\
23.4\end{array}$ & $\begin{array}{l}22.99 \\
23.37\end{array}$ & $\begin{array}{c}3-\mathrm{OH} 17: 0 \\
?\end{array}$ & & & & & & & & 2.0 & & \\
\hline
\end{tabular}

a Equivalent chain length: Values are an average of its peaks.

b $i$, iso; ai, anteiso; 3-OH, 3-hydroxy. 
Gram-negative obligately anaerobic rods.

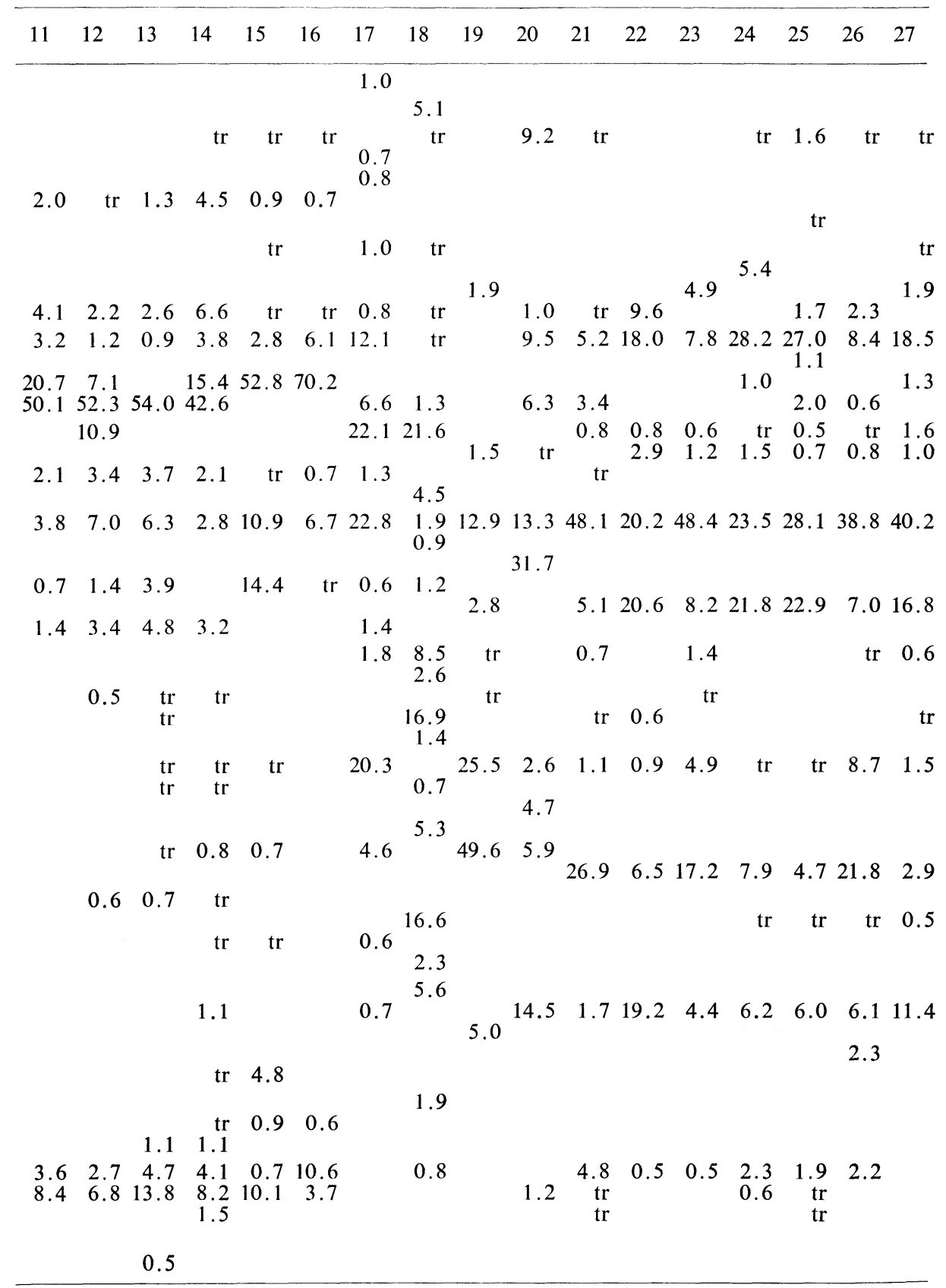

c Corresponds to number in Table 1.

$d$ Number refers to percentage of total acids: tr, less than $0.5 \%$; blank spaces, not detected. 
few differences that depended on species and/or strains used were found. $B$. succinogenes had mainly 16:0, 15:0, and 18:0 acids. An acidic dinitrophenylhydrazine-positive spot, assumed as a dimethylacetal, was detected, corresponding to authentic standard by thin-layer chromatography with toluene: ether (97: 3, $\mathrm{v} / \mathrm{v}$ ) as a solvent, but these peaks on gas chromatogram agreeing with this substance was not fully analyzed. The major fatty acids were 15:0, 17: 1, and 3-OH-13:0 in B. hypermegas, 18:1, 18:0, and 16:0 in B. furcosus, 16:1,3-OH-14:0, and 16: 0 in B. multiacidus, and 16:0,18:1, and 14:0 in B. amylophilus. The most abundant fatty acids in Fusobacterium species were 16:0, 16:1, 14: 0, and 3-OH14: 0 .

\section{Numerical analysis}

After calculating the correlation coefficient among all the strains used by BERGAN's formula (11), a dendrogram based on their fatty acid composition was made (Table 3). High similarity indices $(S \geq 0.95)$ were found among inter-subspecies of $B$. fragilis. High value $(S \geq 0.94)$ was found between $B$. fragilis and B. melaninogenicus, excepting B. melaninogenicus var. asaccharolyticus. Therefore, it seems difficult to distinguish $B$. fragilis from $B$. melaninogenicus simply on the basis of fatty acid composition using a packed column GLC, but a lower similarity was observed between B. ruminicola var. ruminicola and B. fragilis $(S=0.842)$. Also, similarity between B. oralis ATCC 15930 and B. fragilis, and that between B. rumini-

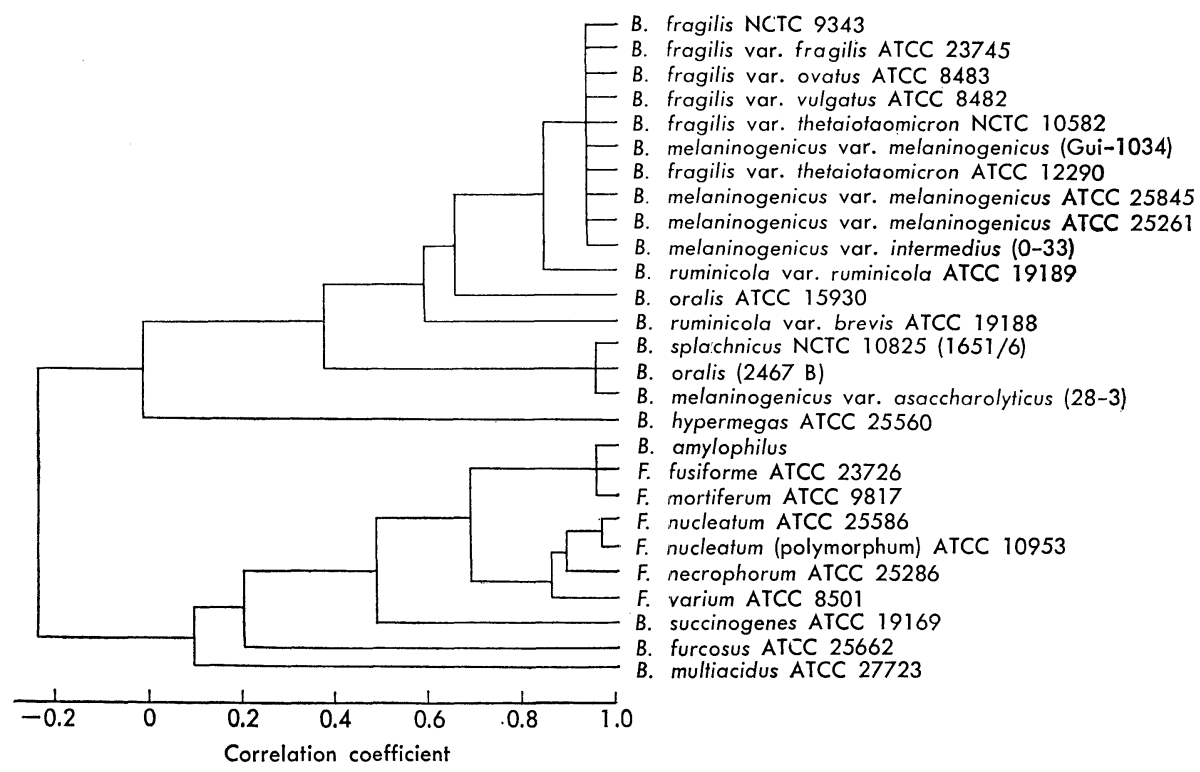

Fig. 3. Dendrogram of Gram-negative obligately anaerobic rods based on their fatty acid composition. 
cola var. ruminicola and $B$. fragilis is 0.660 and 0.604 , respectively. High value ( $S \geq 0.95$ ) was noted among three strains including B. splachnicus, B. oralis (2467 B), and $B$. melaninogenicus var. asaccharolyticus, but these strains exhibited the value $(S \geq 0.379)$ away from that of the strains including B. fragilis, B. oralis ATCC 15930, B. melaninogenicus, and B. ruminicola. Bacteroides amylophilus showed a higher degree of similarity to Fusobacterium species rather than to Bacteroides species, that is, high similarity indices $(S \geq 0.96)$ were obtained between $B$. amylophilus and two Fusobacterium species ( $F$. fusiforme and $F$. mortiferum). In respect to the interspecies similarity of Fusobacterium, similarity values more than 0.69 were obtained. A low similarity $(S=0.49)$ was seen between $B$. succinogenes and Fusobacterium spp. B. hypermegas, B. furcosus, and B. multiacidus showed a very low degree of similarity to the bacteria mentioned above, maximal value was 0.20 .

\section{DISCUSSION}

Previously, Fritsche (5) reported that 3-OH-16: 0 and/or 3-OH-iso-17: 0 was present in lipids from $B$. fragilis and $B$. melaninogenicus. Our results showed these fatty acids in large quantities were also contained in B. oralis and B. ruminicola. STOFFEL et al. (13) analysed sphingolipids from $B$. fragilis var. vulgatus and reported that their main fatty acid was 3-OH-16:0. In sphingolipids from $B$. fragilis NCTC 9343, 3-OH-iso-17:0 (14) was their major fatty acid. Hence it is considered that these 3-hydroxy-fatty acids are derived from sphingolipids that are present in these bacteria. Hydroxy-fatty acids (15) are generally found in lipopolysaccharide (LPS) of some Gram-negative bacteria. HASE et al. (16) analyzed the fatty acid compositions of LPS from several Fusobacterium species, and it was found that a large amount of 3-hydroxy-fatty acids was present in LPS of these organisms. The results of our study demonstrated that Fusobacterium species were rich in 3-OH14: 0 . This acid, therefore, was presumed to be of LPS origin.

UCHIDA and Mogr (17) obtained useful information about the relationships between bacteria and the other from the point of fatty acid biosynthesis. Octadecenoic acid in B. amylophilus and Fusobacterium species was composed of cisvaccenic acid, whereas that in other Bacteroides was composed of oleic acid. This difference in fatty acids serves as a useful taxonomic criterion.

The genus Bacteroides (2) is characterised by the formation of succinic acid and acetic acid as a final product of the metabolism. Fusobacterium species produce a large amount of butyric acid from glucose while most Bacteroides species do not. The major fatty acids of B. fragilis, B. oralis ATCC 15930, and B. melaninogenicus, except $B$. melaninogenicus var. asaccharolyticus, that produced a large amount of succinic acid, were anteiso-15: 0, 3-OH-iso-17: 0, etc., but in spite of producing succinic acid, the fatty acid compositions of $B$. amylophilus were similar to that of Fusobacterium rather than to Bacteroides mentioned above. B. succinogenes that produces succinic acid also showed fatty acid compositions not to those 
of these Bacteroides. The fatty acid compositions of B. multiacidus, B. hypermegas, and $B$. furcosus which produce no or little succinic acid, were different from those of other Bacteroides and Fusobacterium. FRITSCHE (5) claimed that the presence of phosphosphingolipids should be an important feature to define the genus Bacteroides. At present, we are of the same opinion. Accordingly, it is considered that B. amylophilus, B. succinogenes, B. hypermegas, B. furcosus, and B. multiacidus may be excluded from genus Bacteroides because these bacteria do not contain sphingolipids (6) and their fatty acid compositions are different from those of Bacteroides that contain sphingolipids. MitsuoKA et al. (18) studied a variety of characters of $B$. multiacidus and mentioned that it seemed appropriate that this organism was retained within the genus Bacteroides, because at present there is insufficient evidence to prepare a new genus. Further investigations are needed in order to place these bacteria that do not contain sphingolipids in a suitable position on taxonomy. Fritsche (5) placed a few bacteria in genus Bacteroides because they contained sphingolipids, although they produced butyric acid. There are three strains that come under this category in our experiment, that is, B. splachnicus that FrITSCHE studied after Dr. Welner offered it to him, B. oralis (2467 B), and B. melaninogenicus var. asaccharolyticus obtained from Dr. Ueno. They produce butyric acid, and their main fatty acids are iso-15:0 and 3-OH-iso-17:0, and consequently similarity in their values is high, but low between them and $B$. fragilis groups. FINEGOLD and BARNES (19) proposed that the asaccharolytic strain at present known as $B$. melaninogenicus var. asaccharolyticus should be reclassified in a separate species, B. asaccharolyticus, by reason of the difference of its DNA base ratio and so on from those of other two B. melaninogenicus subspecies. In case the presence of sphingosine bases is confirmed, it seemed to be proper to leave three strains in our study in the member of genus Bacteroides.

$B$. succinogenes or $B$. amylophilus formed a cluster distinct from that of the groups centering around $B$. fragilis or B. splachnicus in the dendrogram based on similarity values. JANTZEN et al. (20) have reported that the results of grouping by clustering based on the technique like this were in good accordance with those obtained by the conventional techniques in Moraxella, Acinetobacter, and others. IкEмото et al. (21) made use of this technique in the genus Pseudomonas and obtained the results that agreed fairly well with those in the past. However, it may not be correct to judge immediately this technique as being valid generally in grouping of bacteria. For example, even though similarity value between $B$. amylophilus and Fusobacterium species is high, it cannot be considered that they belong to the same genus if a great difference in the mode of energy metabolism is taken into consideration. This is the same fact it does not always follow that they belong to the same genus, even if a very similar value in $\mathrm{GC} \%$ is obtained between two species of bacteria. Therefore, at present we consider that it is useful to calculate the correlation coefficient by the method like this to find a clue for comparing an unknown bacterium with a known bacterium. First, a semiquantitative-quali- 
tative analysis of products is especially essential to the diagnosis of an anaerobe. Then, as a technique on an extra frame of this analysis, the method mentioned above will be easily accepted to a laboratory which deals with an anaerobe.

Results of field isolates will be reported in the next paper. The accumulation of a knowledge like this in many bacteria will enable their arrange more rationally than ever, including other information, as well as the knowledge based on tests needed to arrange more rationally.

We wish to thank Dr. R. Tanaka, Yakult Institute for Microbiological Research, Kunitachi, Tokyo, Dr. K. Ueno, Gifu University, Gifu, Dr. T. Mitsuoka, Institute of Physical and Chemical Research, Wako, Saitama, and Dr. H. Welner, Bonn University, Bonn, West Germany, for supplying the strains used in this study. We would also like to thank Dr. T. Makino, Yakult Institute for Microbiological Research, for GC-MS spectrometric analyses of fatty acids.

\section{REFERENCES}

1) K. Abel-de H. Schmertzing and J. I. Peterson, J. Bacteriol., 85, 1039 (1963).

2) L. V. Holdeman and W. E. C. Moore, In Bergey's Manual of Determinative Bacteriology, 8th Ed., ed. by R. E. Buchanan and N. E. Gibbons, The Williams and Wilkins Co., Baltimore (1974), p. 385.

3) A. T. Willis, S. E. J. Young, and I. R. Ferguson, In Infection with Non-sporing Anaerobic Bacteria, ed. by I.M.A. Phillips and M. Sussman, Churchill Livingstone Co., London (1974), p. 189.

4) T. Hofstad, J. Gen. Microbiol., 85, 314 (1974).

5) D. Fritsche, Zntralbl. Bakteriol. Parasitenk. Infektionskr. Hyg., Abt. 2, Orig. A, 233, 64 (1975).

6) E. Miyagawa, R. Azuma, and T. Suto, J. Gen. Appl. Microbiol., 24, 341 (1978).

7) G. Prefontaine and F. L. Jackson, Int. J. Syst. Bacteriol., 22, 210 (1972).

8) R. Azuma and T. Suto, Proc. Ist Int. Conf. Culture Collect., p. 493 (1970).

9) M. P. Bryant and L. A. Burkey, J. Dairy Sci., 36, 205 (1953).

10) B. L. Brian and E. W. Gardner, Appl. Microbiol., 16, 549 (1968).

11) T. BERGAN, Bacteriol. Rev., 35, 379 (1972).

12) I. Yano, Y. Ohno, M. Masui, K. Kato, E. Yabuuchi, and A. Ohyama, Lipids, 11, 685 (1976).

13) W. Stoffel, K. Dittmar, and R. Wilmes, Hoppe-Seyler's Z. Physiol. Chem., 356, 715 (1975).

14) E. Miyagawa, R. Azuma, and T. Suto, 50th Annu. Meet. Jpn. Soc. Bacteriol., p. 176 (1976), abstract in Japanese.

15) O. Lüderitz, Ch. Galanos, V. Lehmann, and Th. Rietschel, J. Hyg. Epidemiol. Microbiol., 18, 381 (1974).

16) S. Hase, T. Hofstad, and E. T. Rietschel, J. Bacteriol., 129, 9 (1977).

17) K. Uchida and K. Mogi, J. Gen. Appl. Microbiol., 18, 109 (1972).

18) T. Mitsuoka, A. Terada, K. Watanabe, and K. Uchida, Int. J. Syst. Bacteriol., 24, 35 (1974).

19) S. M. Finegold and E. M. BARnes, Int. J. Syst. Bacteriol., 27, 388 (1977).

20) E.-B. Jantzen, K. T. Bergan, and K. Bovre, Acta Pathol. Microbiol. Scand., Sect. B, 82, 767 (1974).

21) S. Ikemoto, H. Kuraishi, K. Komagata, R. Azuma, T. Suto, and A. Morooka, J. Gen. Appl. Microbiol., 24, 199 (1978). 